\title{
PERMETHRIN FOR THE CONTROL OF LEPIDOPTERAN INSECT PESTS IN NEW ZEALAND
}

\author{
I.F. JACKSON and D.P. GRAHAM \\ ICI Tasman Limited \\ Palmerston North and Hamilton
}

Summary

Permethrin is a synthetic pyrethroid insecticide with an extremely high level of activity at very low application rates, but is of notably low mamalian toxicity. Permethrin's insecticidal activity on plants has been found to persist for up to three weeks even though permethrin residues on plants following treatment are minimal. Permethrin is particularly active on Lepidoptera, and in New Zealand trials has provided effective control of leaf roller species (mainly Epiphyas postvittana) and codling moth (Laspeyresia pomonella) in apples, Helicoverpa armigera conferta on sweetcorn and tomatoes, and diamond back moth (Plutella xylostella) and white butterfly (Pieris rapae) on cauliflowers.

\section{INTRODUCTION}

Permethrin, a new synthetic pyrethroid insecticide of notably low mammalian toxicity, was discovered by $\mathrm{Dr} \mathrm{M}$. Elliot at Rothamstead Experimental Station in the United Kingdom in 1975. The chemical is being developed internationally for a wide range of agricultural, horticultural and public health uses.

Permethrin, formerly known as NRDC 143 and PP 557 is a broad spectrum insecticide exhibiting its highest degree of activity against Lepidoptera insects. It is effective at rates of $25-125 \mathrm{~g} / \mathrm{ha}$ and persists on plant surfaces for a longer period than many commonly used insecticides. At slightly higher rates it shows worthwhile activity on Hemiptera, Diptera and Coleoptera. Permethrin presently controls most strains of insects which have become resistant to a range of organochlorine and organophosphate insecticides.

Lepidopteran insect species are economic pessts of a number of New Zealand crops and can severely affect crop quality and yield if not adequately controlled. The larvae of tomato fruitworm or corn earworm $(H$. armigera conferta) can cause extensive damage to the fruit of tomatoes and cobs of sweetcorn. (Valentine, 1975). In vegetable brassicas, white butterfly larvae and diamond back moth larvae are voracious feeders, eating large ragged holes in the leaves (Lowe 1956). Larvae of codling moth and several leaf roller species, (mainly light brown apple moth) (Epiphyas postvittana) if not controlled, can cause extensive damage to the foliage and fruit of apples resulting in a downgrading in quality.

\section{Physical properties}

Unlike natural pyrethrins, permethrin is relatively stable to degradation in sunlight and therefore, normally provides control of insects on plant surfaces for up to three weeks, even under extremes of temperature and sunlight. However, its degradation is rapid in soil and water. Permethrin is rainfast but does not possess systemic, fumigant, or translaminar activity.

Proc. 32nd N.Z. Weed and Pest Control Conf. 


\section{New Products}

\section{Toxicology}

Permethrin possesses an extremely low acute mammalian toxicity, the L D 50 to male rate being $\$ 4000 \mathrm{mg} / \mathrm{kg}$. It is subject to speedy bio-degradation into non toxic metabolites and is completely excreted by warm blooded animals. In long term feeding studies, permethrin did not cause mutagenic or tetratogenic effects. However, as a directed treatment, permethrin is toxic to bees and although toxic to fish, recommended rates of application pose no hazard to aquatic life.

\section{Residues and persistence}

At normal rates of use, residues of permethrin on treated crops are very low, generally less than $1 \mathrm{ppm}$ on apples, cabbages and tomatoes. When considered along with the low toxicity, these low residue levels mean that crop withholding periods are likely to be short. Although residue levels are low, permethrin generally displays insecticidal activity for periods longer than commonly used carbamate and organo-phosphate insecticides.

\section{Biological action}

Permethrin is fast acting and works essentially by contact and as a stomach poison. Whilst effective against all stages of insect development it is particularly noteworthy for its larvicidal action. Permethrin exerts a significant inhibition of feeding even after the concentration of the chemical on the plant surface has dropped to sub-lethal levels. It has been observed that larvae of some species will actually die of starvation in preference to feeding on treated surfaces, and that flying adults preferentially selected non-treated surfaces on which to oviposit.

\section{METHODS}

The New Zealand evaluation of permethrin has included replicated trials and block evaluations on tomatoes, apples, vegetable brassicas and sweetcorn.

\section{Tomatoes}

Two replicated trials and three block evaluations were conducted in tomatoes. Rate of permethrin were evaluated and compared with the standard rate of methomyl. The plot size was from $5-10 \mathrm{~m}$ of row with five or six replicates in a randomised block design. Treatments were applied by a modified Oxford plot sprayer in 1000 litres/ha.

Both trials were treated on a 3 weekly schedule, from transplanting to final harvest and included treatments to control bacterial and fungal diseases. The trials were progressively harvested to obtain yields and regular assessments made for tomato fruitworm damage by inspecting 100 randomly selected tomato fruits /plot in Trial 1 and 50 /plot in Trial 2.

Two non replicated block trials were carried out in Hastings and one in Gisborne. The treatment was applied by growers as part of their normal spray schedule and compared permethrin $37.5 \mathrm{~g} / \mathrm{ha}$ to their standard insecticide treatment. The permethrin block sizes were generally about 1 ha. Inspections for tomato fruitworm damage were made over the harvest period.

\section{Sweetcorn}

One replicated plot trial and three aerially applied block evaluations were carried out to determine the activity of permethrin against corn earworm. While blocks 1 and 2 were not replicated, block 3 consisted of two replicates of each treatment. A plot size of $10 \mathrm{~m} \mathrm{x}$ six rows was used in the plot trial with each treatment replicated four times. At the time of treatment $35 \%$ of the cobs were infested with corn earworm and $6 \%$ of 


\section{New Products}

cobs were already damaged by insect feeding. Treatments were applied with a knapsack sprayer fitted with a flood jet nozzle delivering 105 litres/ha.

Assessments of corn earworm infestation and cob damage were made on the centre two rows of the plot at intervals following treatment.

The blocks were sprayed by helicopter calibrated to apply 110 litres/ha. Block sizes were about 2 ha with the remaining part of the field being treated with methomyl $(300 \mathrm{~g} / \mathrm{ha})$. Blocks were assessed for corn earworm infestation and damage at intervals following treatment in blocks 1 and 2 by sampling 100 cobs, and in block 3 by sampling 200 cobs /block on a diagonal across the treated area.

\section{Vegetable brassicas}

Two trials were laid down in the Christchurch area on 1 week transplanted cauliflowers. In both trials treatments were replicated four times, in a randomised block design, with a plot size of $4 \mathrm{~m} \mathrm{x}$ two rows. The incidence of insect pests was ascertained at treatment, and following treatment, at the intervals shown in Table 4. These counts entailed the destructive harvesting of two plants /plot.

On Trial 1 there was a mean of 6 larvae /plant and in Trial 2, 3.4 larvae and 5.6 aphids /plant present at treatment in mid January. The assessment on both trials showed there to be equal numbers of diamond back moth (DBM) and white butterfly (WBF) larvae. Insecticides were applied with a modified Oxford plot sprayer in 250 litres/ha. In addition to insect counts, a visual assessment of consumer acceptibility was made at the time of harvesting, based on the amount of insect damaged foliage per plant.

\section{Apples}

A replicated trial carried out in Hastings in 1977 on 'Sturmer Pippin' apples and several block evaluations are reported.

The trial consisted of four replicates of single tree plots using a randomised block design. Treatments were applied on a 14-21 day schedule as a dilute spray to the point of run-off. The insecticide treatments were applied in mixture with a normal fungicide and miticide programme.

Leaf assessments of leafroller and leaf curling midge (Pasyneura mali) inf estation were made by assessing 25 laterals / tree.

At harvest, 250 apples /tree were assessed to ascertain levels of insect damage and any chemical effects on fruit finish.

The treatment of commercial blocks was carried out by growers as part of their normal spraying schedule and a comparison made between permethrin and azinphos-methyl.

\section{Tomatoes}

\section{RESULTS}

The results presented in Table 1 show that in both trials all treatments provided a highly significant reduction in fruitworm damage compared to untreated, while in Trial 1 permethrin $25-50 \mathrm{~g} / \mathrm{ha}$ was significantly better than methomyl. The pirimiphos-methyl plus permethrin mixture provided a very high level of insect control and in both trials this treatment gave the highest yield. Regression analysis on the data on Trial 1 showed a negative correlation between the incidence of fruitworm damage and fruit yield $(R=0.68)$, thus confirming the insect can significantly affect yield.

The two block evaluations in Hastings, sprayed on a two weekly schedule with peremthrin at $37.5 \mathrm{~g} / \mathrm{ha}$ showed virtually no insect damage throughout the season as was also the case for the methomyl $400 \mathrm{~g} / \mathrm{ha}$ blocks. 
New Products

Table 1. Effect of treatment on fruitworm damage and tomato yield (var, "Scoresby Dwarf")

\begin{tabular}{|c|c|c|c|c|c|c|c|}
\hline \multirow[t]{2}{*}{ Treatment } & \multirow{2}{*}{$\begin{array}{l}\text { Rate } \\
\mathrm{g} / \mathrm{ha}\end{array}$} & \multicolumn{3}{|c|}{ Trial 1 (Hastings) $1977 / 78$} & \multicolumn{3}{|c|}{ Trial 2 (Manawatu) $1978 / 79$} \\
\hline & & \multicolumn{2}{|c|}{$\begin{array}{c}\% \text { Fruitworm } \\
\text { damage } \\
27 \mathrm{Feb} 6 \mathrm{Apr}\end{array}$} & $\begin{array}{l}\text { Yield } \\
\text { t/ha }\end{array}$ & \multicolumn{2}{|c|}{$\begin{array}{l}\text { \% Fruitworm } \\
\text { damage } \\
24 \mathrm{Feb} 14 \mathrm{Mar}\end{array}$} & $\begin{array}{l}\text { Yield } \\
\text { t/ha }\end{array}$ \\
\hline untreated & & $18 \mathrm{a}$ & $32 \mathrm{a}$ & $63.4 \mathrm{c}$ & $8.1 \mathrm{a}$ & $26 \mathrm{a}$ & $56.9 \mathrm{~b}$ \\
\hline methomyl & 400 & $8 \mathrm{~b}$ & $20 \mathrm{~b}$ & $72.5 \mathrm{bc}$ & $2.2 \mathrm{~b}$ & $4.0 \mathrm{~b}$ & $67.7 \mathrm{a}$ \\
\hline permethrin & 50 & $0.2 \mathrm{~d}$ & $7 \mathrm{c}$ & $78.3 \mathrm{ab}$ & $0.7 \mathrm{~b}$ & $0.5 \mathrm{~b}$ & $69.2 \mathrm{a}$ \\
\hline permethrin & 37.5 & $0.8 \mathrm{~d}$ & $6 \mathrm{c}$ & $78.1 \mathrm{ab}$ & $1.0 \mathrm{~b}$ & $1.0 \mathrm{~b}$ & $68.6 \mathrm{a}$ \\
\hline permethrin & 25 & $1.2 \mathrm{~d}$ & $9 \mathrm{c}$ & $74.5 \mathrm{ab}$ & $2.6 \mathrm{~b}$ & $0.5 \mathrm{~b}$ & $68.2 \mathrm{a}$ \\
\hline permethrin & 12.5 & $5.2 \mathrm{c}$ & $17 \mathrm{~b}$ & $75.2 \mathrm{ab}$ & - & - & -- \\
\hline pirimiphos-methyl & 500 & $7.3 \mathrm{bc}$ & $17 \mathrm{~b}$ & $69.1 \mathrm{bc}$ & - & - & - \\
\hline $\begin{array}{l}\text { pirimiphos-methyl } \\
+ \text { permethrin }\end{array}$ & $\begin{array}{r}500 \\
+25\end{array}$ & $1.5 \mathrm{~d}$ & $7 \mathrm{c}$ & 840 & $05 \mathrm{~h}$ & $15 \mathrm{~b}$ & $72.8 \mathrm{a}$ \\
\hline & & & & & & & \\
\hline $\mathrm{CV} \%$ & & 44 & 35 & 11.5 & 105 & 82 & 11 \\
\hline
\end{tabular}

In Gisborne, permethrin at $37.5 \mathrm{~g} /$ ha provided slightly better control ( $2 \%$ damaged) on 'Castlong' tomatoes compared to methomyl at $400 \mathrm{~g} / \mathrm{ha}(5 \%$ damaged) at a February 16 assessment. At harvest, a $10 \mathrm{~m}$ row length of permethrin treated tomatoes was completely clean, while on the same length row treated with methomyl, 10 damaged tomatoes were observed. On a $50 \mathrm{~m}$ row length 10 tomatoes were damaged on the permethrin block while 38 damaged on the methomyl area.

\section{Sweetcorn}

Table 2. Corn earworm incidence and \% cob damage in replicated plot tria]

\begin{tabular}{lrrlll}
\hline Treatment & $\begin{array}{c}\text { Rate } \\
\text { g/ha }\end{array}$ & $\begin{array}{c}\text { Day 5 } \\
\text { cobs with } \\
\text { corn earworm }\end{array}$ & $\begin{array}{c}\text { D cob } \\
\text { damage }\end{array}$ & $\begin{array}{c}\text { \% cobs with } \\
\text { corn earworm }\end{array}$ & $\begin{array}{c}\text { \% cob } \\
\text { damag }\end{array}$ \\
\hline untreated & 300 & $32 \mathrm{a}$ & $38 \mathrm{a}$ & $27 \mathrm{a}$ & $39 \mathrm{a}$ \\
methomyl & $14 \mathrm{~b}$ & $21 \mathrm{ab}$ & $9 \mathrm{~b}$ & $17 \mathrm{~b}$ \\
permethrin & 100 & $6 \mathrm{~b}$ & $10 \mathrm{~b}$ & $2 \mathrm{~b}$ & $10 \mathrm{~b}$ \\
permethrin & 75 & $6 \mathrm{~b}$ & $10 \mathrm{~b}$ & $2 \mathrm{~b}$ & $11 \mathrm{~b}$ \\
permethrin & 50 & $7 \mathrm{~b}$ & $11 \mathrm{~b}$ & $3 \mathrm{~b}$ & $14 \mathrm{~b}$ \\
permethrin & 25 & $19 \mathrm{~b}$ & $21 \mathrm{ab}$ & $4 \mathrm{~b}$ & $19 \mathrm{~b}$ \\
\hline CV\% & 57 & 65 & 101 & 63 \\
\hline
\end{tabular}

Assessments at day 5 and 13 presented in Table 2, show all chemica treatments to have provided a significant reduction in corn earworm infestation and cob damage compared to untreated. Permethrin at $25-10 \mathrm{C}$ $\mathrm{g} / \mathrm{ha}$ provided at least equivalent insect control and reduction in col damage to methomyl $(300 \mathrm{~g} / \mathrm{ha})$.

Results of all block evaulations presented in Table 3 show permethrir $(50 \mathrm{~g} / \mathrm{ha})$ to provide superior control of corn earworm to that afforded by methomyl $(300 \mathrm{~g} / \mathrm{ha})$. In block 1 at the time of harvest, insect number: were beginning to build up on the methomyl treated area while they continued to decrease on the permethrin block. 
New Products

Table 3. Sweetcorn block evaluation results.

\begin{tabular}{|c|c|c|c|c|c|c|c|}
\hline \multirow{2}{*}{$\begin{array}{l}\text { Block } \\
\text { Location } \\
\text { Days following treatment }\end{array}$} & & \multicolumn{3}{|c|}{$\stackrel{1}{\text { Muriwai }}$} & \multirow{2}{*}{$\begin{array}{c}2 \\
\text { Tolaga Bay } \\
15\end{array}$} & \multicolumn{2}{|c|}{$\begin{array}{l}3 \\
\text { Manutuke }\end{array}$} \\
\hline & & 0 & 5 & 13 & & & 17 \\
\hline Treatment & $\begin{array}{l}\text { Rate } \\
\mathrm{g} / \mathrm{ha}\end{array}$ & & & & & & \\
\hline $\begin{array}{l}\text { permethrin } \\
\% \text { cobs infested by }\end{array}$ & 50 & & & & & & \\
\hline corn earworm & & 31 & 8 & 3 & 6 & 35 & 7 \\
\hline$\%$ cob damage & & 6 & 12 & 12 & 6 & 12 & 18 \\
\hline $\begin{array}{l}\text { methomyl } \\
\% \text { cobs infested by }\end{array}$ & 300 & & & & & & \\
\hline $\begin{array}{l}\text { corn earworm } \\
\% \text { cob damage }\end{array}$ & & $\begin{array}{r}31 \\
6\end{array}$ & $\begin{array}{r}5 \\
13\end{array}$ & $\begin{array}{l}10 \\
18\end{array}$ & $\begin{array}{l}37 \\
32\end{array}$ & $\begin{array}{l}35 \\
12\end{array}$ & $\begin{array}{l}13 \\
25\end{array}$ \\
\hline
\end{tabular}

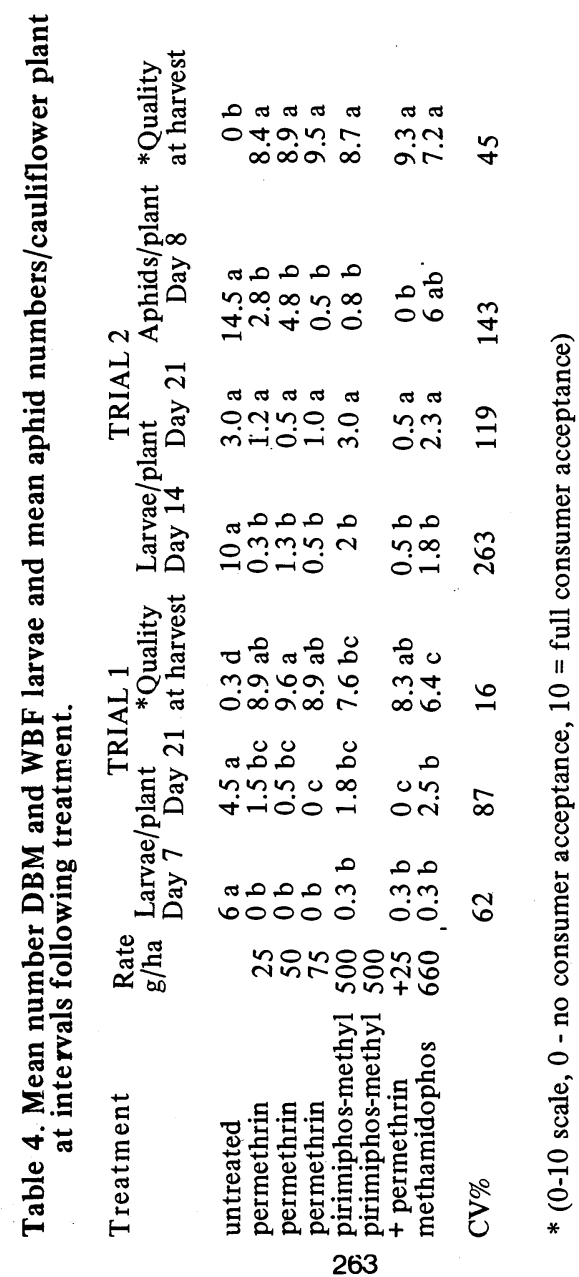




\section{New Products}

Vegetable brassicas

The results of both trials are presented in Table 4 . On trial 1 the number of larvae /plant 7 days post spraying showed no significant differences between treatments with all treatments significantly better than untreated. At 21 days post spraying all treatments were significantly superior to untreated with permethrin $(75 \mathrm{~g} / \mathrm{ha})$ and the mixture pirimiphos methyl $(500 \mathrm{~g} / \mathrm{ha})+$ permethrin $(25 \mathrm{~g} / \mathrm{ha})$ being significantly superior to methamidophos. These differences were most obvious when visual assessments of consumer acceptance were compared. Similar results were recorded on Trial 2 with all treatments being significantly better than untreated at 14 days following spraying. There were no significant differences between treatments, but in all counts permethrin recorded fewer insects than the methamidophos treatment.

All treatments in Trial 2 apart from methamidophos, provided a significant reduction in aphid numbers, while pirimiphos-methyl $500 \mathrm{~g}+$ permethrin $25 \mathrm{~g} / \mathrm{ha}$ achieved complete control of aphids.

\section{Apples}

Table 5. Assessments of apple leaf and fruit damage by leaf curling midge, leaf roller and codling moth.

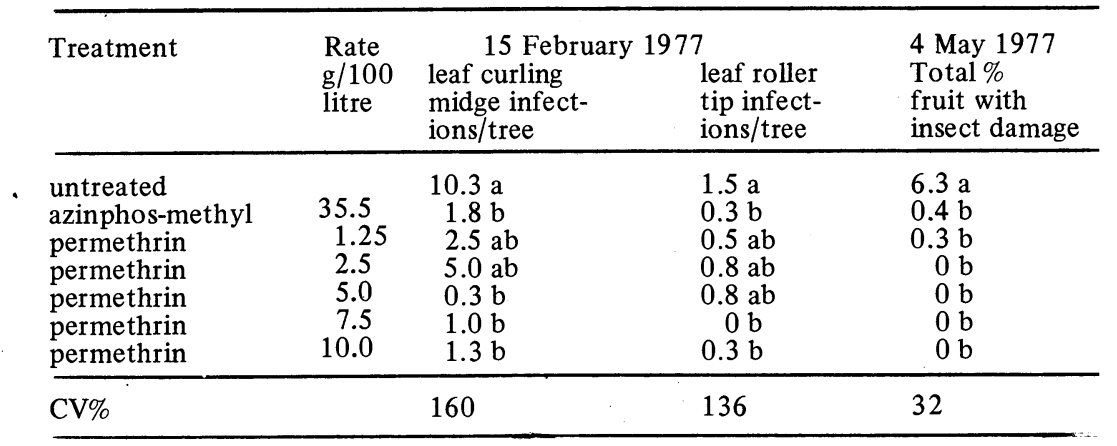

The assessment of February 15, on Table 5, showed the very low incidence of leaf roller tip damage with all treatments harbouring slightly less leaf roller than untreated. At rates of $5 \mathrm{~g} / 100$ litres and above permethrin provided control of leaf curling midge comparable tc azinphos0methyl, whilst all treatments were significantly superior tc untreated.

Fruit inspected for insect damage showed all treatments had markedly less insect damage than the untreated. Permethrin at all rates evaluated provided a similar level of control to azinphos-methyl. In addition nc treatment caused detectable phytotoxicity for the duration of the trial and assessments of fruit finish showed permethrin treated apples to be comparable to azinphos-methyl.

Table 6 presents results of block evaulations which substantiate the high level of leaf roller and codling moth control provided by permethrin and was equivalent to the commercial standard, azinphos-methyl. No adverse chemical effects have been recorded as a result of using permethrin over a wide variety of species. However, the use of permethrin in some orchards has had a negative effect on European red mite (Panonychus ulmi) control. In these trials permethrin and other pyrethroids have been 
New Products

Table 6. Insect damage to apples on block evaluations

\begin{tabular}{|c|c|c|c|c|c|c|}
\hline \multirow[b]{2}{*}{$\begin{array}{l}\text { Location } \\
\text { Variety }\end{array}$} & \multicolumn{5}{|c|}{$\%$ damaged fruit } & \multirow[b]{2}{*}{$\begin{array}{l}\text { P.N. (1979) } \\
\text { Granny } \\
\text { Smith } \\
\end{array}$} \\
\hline & $\begin{array}{l}\mathrm{g} / 100 \\
\text { litres }\end{array}$ & $\begin{array}{l}\text { Hastings } \\
\text { Granny } \\
\text { Smith } \\
\end{array}$ & $\begin{array}{l}\text { (1978) } \\
\text { Sturmer }\end{array}$ & $\begin{array}{l}\text { Nelson } \\
\text { Granny } \\
\text { Smith }\end{array}$ & $\begin{array}{l}\text { (1978) } \\
\text { Sturmer }\end{array}$ & \\
\hline $\begin{array}{l}\text { Treatment } \\
\text { permethrin } \\
\text { permethrin } \\
\text { azinphosmethyl }\end{array}$ & $\begin{array}{l}2.5 \\
3.75 \\
37.5\end{array}$ & $\begin{array}{l}0.3 \\
0 \\
0.3\end{array}$ & $\begin{array}{l}0.7 \\
0.3 \\
1.0\end{array}$ & $\begin{array}{l}1.6 \\
0.7 \\
2.6\end{array}$ & $\begin{array}{l}2.6 \\
2.6 \\
2\end{array}$ & $\begin{array}{l}0^{-} \\
1.0\end{array}$ \\
\hline
\end{tabular}

found to be highly toxic to the European red mite predator (Typhlodromus pyri).

\section{DISCUSSION}

The reported trials carried out in New Zealand have confirmed the high level of insecticidal activity of permethrin and have shown that at approximately one tenth the application rate of commercially available standards it provides equivalent or superior control of lepidoptera insect pests, on a wide range of crops.

Results on vegetable crops illustrate the value of permethrin. On tomatoes, permethrin $(37.5 \mathrm{~g} / \mathrm{ha})$ provided a significant reduction in tomato fruitworm damage, while under commercial application treatment with permethrin $(37.5 \mathrm{~g} / \mathrm{ha})$ resulted in near insect damage free tomato crops. The reduction in tomato fruitworm damage in trials, resulted in higher yields being attained. Permethrin applied at $37.5 \mathrm{~g} / \mathrm{ha}$ in both trials resulted in significant increases in yield of $14.7 \mathrm{t} / \mathrm{ha}$ and $11.7 \mathrm{t} / \mathrm{ha}$ repectively over untreated.

Similar results were recorded in the control of corn earworm where permethrin applied at $50 \mathrm{~g} / \mathrm{ha}$ and above substantially reduced the number of corn earworms infesting sweetcorn cobs. The high level of control resulted in a reduced proportion of insect damaged cobs on permethrin treated areas from all sites.

In sweetcorn permethrin will provide an advantage over currently used insecticides which because of their short residual life are not normally applied until 2 weeks before harvest, when in many cases insect damage has already occurred. Permethrin which provides effective and extended control of the corn earworm will therefore, allow greater flexibility in time of crop spraying in relation to harvest.

On cauliflowers permethrin $(50 \mathrm{~g} / \mathrm{ha})$ provided control of diamond back moth and white butterfly comparable to that attained with methamidophos $(660 \mathrm{~g} / \mathrm{ha})$ at 14 days post spraying and significantly better 21 days following spraying, which illustrates the extended insecticidal activity of permethrin over currently used insecticides. This result was highlighted by the fact that permethrin treated plants were of a higher consumer acceptibility than methamidophos treated plants.

Effective control of leaf roller and codling moth in apples with very low rates of chemical $(2.5-3.75 / 100$ litres) was comparable to and in some cases better then the currently used insecticide azinphos-methyl. However, the toxicity of pyrethroid insecticides to the European red mite predator $T$. pyri could result in the need for further miticide applications if pyrethroid insecticides are used when predator mites are present.

Permethrin has also shown a high level of efficacy against whitefly on glasshouse crops, leaf roller species on berryfruits, ornamentals, peaches and kiwifruit and against adult grass grub beetles (Lauren et al 1978). 


\section{New Products}

\section{ACKNOWLEDGEMENTS}

The authors would like to thank the farmers and growers who made trial sites available and for their valuable assistance. The assistance and co-operation of the field staff of the New Zealand Fruitgrowers Federation and J. Wattie Canneries Limited is also gratefully acknowledged. Thanks also to B.P. O'Connor for help and guidance in the trial programme and constructive criticism of the paper.

\section{REFERENCES}

Lauren, D. R., Henzell R. F. and Yortt M. L., 1978. The importance of application time when synthetic pyrethroids are used to control adult grass grubs. Proc 31st N.Z. Weed and Pest Control Conf: 154-59.

Lowe, A.D., 1956. Control of insect pests on brassica crops in New Zealand. N.Z. J. Agric: 94. 341-53.

Valentine, E. W., 1975. Tomato fruitworm, Helocoverpa armigera conferta Huebner, life cycle. DSIR information series No 105/9.

Technical data in Introduction obtained from: ICI Plant Protection Division, 1977. PP557 pyrethroid insecticide technical data sheet. 